\title{
A média felelőssége és lehetőségei a (magyar) rendészeti szervezetek kommunikációjának megjelenítésében
}

\section{Recenzió Molnár Katalin: Rendészeti kommunikáció - a média tükrében címú könyvéről}

\section{URICSKA Erna ${ }^{1}$}

A kiadvány - Rendészeti kommunikáció - a média tükrében - a Dialóg Campus Kiadó gondozásában jelent meg 2018-ban. ${ }^{2}$

A mű szerzője a Nemzeti Közszolgálati Egyetem Rendészettudományi Karának egyetemi docense, közel 30 éve rendészeti kommunikációval foglalkozó szakember, rendőröket oktató tanár, tréner. Van tehát tapasztalata a témában, amelyet ebben a múben összegzett. Miközben sokat publikált a szervezet belső kommunikációjáról, a külsővel most foglalkozott először ilyen mélységben. És jó, hogy végre megtette.

A hazai és nemzetközi szakirodalom rendészeti kommunikációval foglalkozó részének feltérképezését követően azt tapasztaltam, hogy meglehetősen kevés adatot találni a tárgyban. Ennek oka egyrészt a szervezet félkatonai, zárt rendszere lehet. Másrészt a rendőrség maga mint szervezet a legtöbb országban nem tartozik a széles körben elfogadott, társadalmilag is megbecsült szakmák közé, tagjainak viszonya az állampolgárokkal sok esetben problémásnak mondható. Az előbbi állítás feloldásaként a szerző mindjárt a kötet bevezetőjében az alábbit javasolja: „A rendészet sikeres működésének a demokratikus társadalomban elengedhetetlen feltétele a civilekkel való állandó kapcsolattartás, a minél hatékonyabb, zökkenőmentesebb együttműködés."3

Ha ehhez hozzávesszük, hogy Molnár Katalin nevéhez füződik az a hat és fél évvel ezelőtt útjára indított, elsősorban a magyar rendőrségre adaptált úgynevezett Police Café módszer, amely éppen ezt az együttműködést szorgalmazza, akkor érthető, miért hiheti az olvasó, hogy a szerző személyében a témához igencsak értő kalauzra akadt.

URICSKA Erna, mesteroktató, Nemzeti Közszolgálati Egyetem, Rendészettudományi Kar, Idegennyelvi és Szaknyelvi Lektorátus

Erna URICSKA, Master Instructor, Department of Foreign Languages for Specific Purposes, Faculty of Law Enforcement, University of Public Service

https://orcid.org/0000-0002-5371-0650; uricska.erna@uni-nke.hu

Molnár Katalin: Rendészeti kommunikáció - a média tükrében. Budapest, Dialóg Campus, 2018.

Uo. 4. 
$\mathrm{Az}$ itt bemutatott könyv megírása óta már két úgynevezett blogkönyve is megjelent, amelyek bizonyítják a módszer magyarországi térhódítását. ${ }^{4}$

De térjünk vissza a most ajánlandó könyvhöz, amely egy egyetemi pályázati program keretében jelent meg. Bár nyomtatott formában nem foghatjuk kézbe, csak online $^{5}$ érhető el, külsőleg tetszetôs: borítóját a kék és piros szín dominálja, ami nem véletlen, ha egy rendőrségről szóló mưről van szó. A borítón látható a Ludovika főépülete is, illetve a Nemzeti Közszolgálati Egyetem logója, utalva az egyetemi kiadóra.

A mú tartalmilag két nagy szerkezeti egységből áll. Az első rész a rendészeti szervezetekről és ezek kommunikációjának elméleti hátteréről szól, a második rész pedig egy szöveggyüjtemény. A bevezetőben a szerző röviden bemutatja a könyv felépítését és fejezeteit, amelyek a következők:

\section{Bevezetés}

1. A rendőrség társadalmi szerepe

2. A kommunikáció és a rendőrség kapcsolata

3. Rendvédelmi szervek és társadalmi szerepük Magyarországon

4. Szemelvénygyưjtemény

Bibliográfia

Melléklet

A bevezetőből megtudhatjuk, hogy a kiadvány a rendészeti szakújságíró szakirányú továbbképzési szak hallgatóinak íródott, ahogy az alcímben is olvasható. A cél az volt, hogy a képzés során elsajátítható ismeretek segítségével a szakújságírók kompetenciájának fejlesztése által a rendészeti szervezetek nyilvánosság előtti korrekt és hiteles megjelenítését támogassa. A második nagy egységben a rendészeti szakterületek, valamint az ezekhez tartozó leginkább jellemző ügyek bemutatása következik, amelyből kirajzolódik a rendészeti szervezetek külső kommunikációjának két évtizedes hiteles története.

$\mathrm{Az}$ első fejezetben a szerző elhelyezi a rendészetet a társadalomban betöltött szerepe és rendeltetése alapján. Felhívja a figyelmet arra, hogy a modern demokráciákban az állampolgárok és a rendőrség viszonyát a kettőjük között létrejövő kommunikáció, annak minősége, a párbeszédek, azaz a verbális kommunikáció elemei nagyban befolyásolják. Általánosan megfogalmazva: a rendőrség szolgáltatást nyújt a civileknek, amelynek része kell legyen a sokrétú és hiteles, magas színvonalú kommunikációs tevékenység is.

A kommunikáció és rendőrség kapcsolatát részletesebben a második rész tárgyalja, hangsúlyozva a társadalmiszerep-definíció nélkülözhetetlenségét. A kérdéskört egy tágabb fogalmi perspektívába - nevezetesen a rendészeti kommunikációs stratégia rendszerébe - helyezve rávilágít: a rendészeti kommunikációnak nem szabad véletlenszerủ események láncolatának lennie, hanem tudatosan megtervezett folyamat kell

\footnotetext{
Molnár Café Kata: Rendőrkávéházi élményeim. Police Café blogkönyv. Budapest, Rejtjel, 2019.; Molnár Café Kata: Újabb rendôrkávéházi élményeim. Police Café blogkönyv 2. rész. Budapest, Rejtjel, 2020.

5 https://bit.ly/360EYuJ
} 
hogy legyen. E folyamat egyes elemeit részletesen ki is fejti a szerző. Véleménye szerint „a rendészeti kommunikációs stratégia nem más, mint rövid, közép vagy hosszú távú, tudatos megtervezése annak, hogy a rendészeti szerv: 1. hogyan jelenítse meg önmagát a külvilág előtt; 2. hogyan tegye lehetővé a belső információáramlást és ezen keresztül a folyamatos, magas színvonalú, hatékony müködést”. ${ }^{6}$

Látható, hogy kommunikáció kapcsán a szerző itt már nemcsak a verbális és nonverbális elemekre utal, hanem a statikus eszköztárra is. Nyíltan vállalja véleményét, miszerint a hierarchia, a túlszabályozottság gátja a szervezeti kommunikáció fejlődésének, mint ahogyan az állampolgárokkal történő kétoldalú, bizalmon alapuló párbeszéd kialakításának is. Ebben a fejezetben mutatja be a rendőrség írásbeli és szóbeli, illetve belső és külső kommunikációját is. A rendőrség történeti áttekintése során sorra veszi a rendőrségi reformokat, amelyek magyarázatot adnak a szervezet belső és külső kommunikációs folyamataiban bekövetkezett változásokra, illetve ezzel összefüggésben a társadalomban meglévő rendőrkép alakulására is. A szerző vizsgálja, elemzi a rendőrség külső kommunikációját, ennek helyét a PR és média vonatkozásában.

A kötet harmadik fejezetében a négy magyar rendészeti szervezet - a rendőrség, a Nemzeti Adó- és Vámhivatal, a Katasztrófavédelem és a Büntetés-végrehajtási Szervezet - kommunikációjának törvényi szabályozását, sajtószolgálatainak tevékenységét ismerhetjük meg. Röviden említi a közösségi médiát mint az állampolgárokkal kialakítható kommunikációs csatorna új színhelyét és a lehetőségek tárházát. A szerző hangsúlyozza, hogy a kézirat készítésének időpontjában, 2017 őszén csak a katasztrófavédelem vállalt szerepet a közösségi médiában. Az azóta eltelt időszakban már a rendőrség és a Nemzeti Adó- és Vámhivatal szervezeti egységei is megjelentek a különböző közösségi oldalakon.

A kötet utolsó, negyedik fejezetében található az a szemelvénygyüjtemény, amely által betekintést nyerhetünk az egyes rendészeti szervezetek sajtóbeli megjelenítésébe. Hozzáértő szakember segítségével a kiadvány ezen része kiváló gyakorlókönyv lehet annak bemutatására, hogyan, mit és mikor érdemes közölniük (vagy nem közölniük) a szervezeteknek, beleértve a közlési stílusok és a nyelv helyes használatát is.

Összegezve: a kiadvány általános képet ad a rendészeti szervezetek belső és külső kommunikációjáról. Jó alapmú és gondolatébresztő azok számára, akik ismeretlenül mozognak a rendészeti kommunikáció terepén. De sok újdonságot tartogat azoknak is, akik úgy vélik, jól ismerik azt. A téma komolysága, sokrétűsége és összetettsége miatt nehéz róla mindenre kiterjedően és őszintén írni. Ám a rendészeti kommunikációt egyrészt tudományos szinten múvelni és a rendészettudomány elismert szakterületeként képviselni csaknem lehetetlen az őszinteség igénye nélkül. A szerzőnek gondja van erre is, miközben véleményét mindig finoman és kétséget kizáróan a fejlesztés szándékával fejti ki. Másrészt, csak ennek az ismeretanyagnak az átadásával és alkalmazásával lehet e szervezeteknek azt a szerepet betölteniük, amit képviselni hivatottak. Kétoldalú, bizalmon alapuló kommunikációt létrehozni és fenntartani ugyanis csak a funkciójukat

Molnár (2018) i. m. 9. 
betöltő szervezetek képesek. És fordítva: csak az a szervezet képes funkcióját a közösségben maradéktalanul betölteni, amelyik nyitott a közösség irányába.

\section{IRODALOMJEGYZÉK}

Molnár Café Kata: Rendôrkávéházi élményeim. Police Café blogkönyv. Budapest, Rejtjel, 2019.

Molnár Café Kata: Ujabb rendörkávéházi élményeim. Police Café blogkönyv 2. rész. Budapest, Rejtjel, 2020.

Molnár Katalin: Rendészeti kommunikáció - a média tükrében. Budapest, Dialóg Campus, 2018. Elérhetoo: https://bit.ly/360EYuJ 